\title{
By Way of Prologue
}

In the prologue which I wrote in October $195^{2}$ for the first edition, I described how this book had originated in the meetings then held every Monday in the history seminar room of the University of Barcelona. The group was not very large: a dozen friends, either university colleagues or recent graduates who, in the course of plowing through the arid program of studies then in effect, had lost neither their vocation nor their enthusiasm. These conversations, generally dealing with methodology, proved to be extremely stimulating because of the participants' enthusiasm and because absolute freedom of discussion was an established rule. Endless nuances developed as our discussion ranged from comments on a provocative article in the latest issue of a Spanish or foreign publication to very subtle observations in a general evaluation of the work of Karl Jaspers or Arnold Toynbee, who were then in vogue. We often focused our attention, of course, on the problematical aspects of Spain's history, for we were the first to lament the decadence in the post-Civil War period of this type of research, a decadence due as much to the rigidity of old molds of scholarship as to the blithe ideological intuitions of persons who did not want to be bothered with the hard task of digging into archives.

The enthusiasm of our meetings suggested that it might perhaps be of interest to sketch, in a very few pages, the fundamental structure of Spanish history. My purpose, however, was not to produce a new synthesis of the Peninsula's past, but rather to provide a general account of problems on which friends and collaborators, and all who feel a sincere obligation to penetrate into the historic existence of 
Hispania, could base their work. ${ }^{1}$ This idea was still in embryonic form when the amiable pressures of a friend, Santiago Nadal, forced me to act. Nadal asked that I collaborate on a dictionary of politics being prepared under his direction, and we agreed that my contribution should first be published as a short book. It appeared in bookstore windows and had an unexpected, splendid success. This discouraged the editors of the dictionary and they decided not to include my article. I state this purely as bibliographical information, but also as a justification for omitting the note that appeared on the frontispiece of the first edition of this book. ${ }^{2}$

I must attribute its success in the bookstores to the fact that for the first time in fifteen years the public had found a book on Spanish history that was impartial. Based on a dispassionate and concrete analysis of events (at times I would summarize a monograph in one adjective), my assertions were presented simply as working hypotheses, in order to have them perfected or discarded by future research. For this reason I had given the book an extremely modest title. I would attempt only to "approach" the true history of Spain, and I would do so without rhetoric or grandiloquence, but rather with the artisan's effort to persevere in his work and to perfect it.

My Approaches soon called for a new edition. Hispanists in Germany and North America, where my book had been well received, were particularly insistent in their demands. But an "approach" needed some time to mature before a second edition would be possible. I had to observe for a while: what would be the advances in research; which would be the great works of synthesis; what would

\footnotetext{
${ }^{1}$ Hispania, rather than Spain, is the term preferred by Vicens Vives and other Catalan historians. See, for example, the excellent textbook by Santiago Sobrequés Vidal entitled Hispania: Historia politica y cultural de España, (Barcelona, 9th ed., 1960). For these historians, Hispania expresses more adequately the heterogeneous origins of the nation, while Spain is associated with the Castilian-based government developed from the sixteenth century on (see, p. 79-80).

2 The note stated that "with some variations, the text of this work will appear in the Diccionario de politica which is being prepared by the Argos publishing house."
} 
be the orientation of the various schools; what would be the definitive positions? Thus it seemed prudent to wait a few years, particularly because historical science in Spain, which had only recently emerged from its dreams of rhetorical grandeur, had begun developing three movements. These were a revitalization of the philological-institutional school, an abrupt burgeoning of the socioeconomic methods advocated by the Annales in Paris, ${ }^{3}$ and the elimination (less rapidly than had been foreseen) of the "ideologism" 4 of the post-war period. To these movements we must add the contributions (at times, major contributions) of the foreign historians who have concerned themselves with Spain, as well as the equally forceful interpretative works by Américo Castro and Claudio Sánchez Albornoz - two intellectual lights of exiled Spain. ${ }^{5}$

As a consequence, the seven years that separate the first and second appearances of my Approaches may be considered of capital importance in the development of Hispanic historiography in the twentieth century, especially because of the type of publication appearing during that period. Outstanding among these are three general

3 The Parisian historical journal Annales was founded in 1929 by Lucien Febvre (1878-1956) and Marc Bloch (1886-1944). The original title, Annales d'histoire économique et sociale was shortened to Annales d'histoire sociale in 1939, and then broadened to Annales: Economies, sociéties, civilisations in 1946 , reflecting a shift in emphasis within its general socio-economic orientation. Vicens was an enthusiastic advocate of Febvre's ideas, and particularly of the need for "precise quantifiable tata," from 1950, when he attended the Ninth International Congress of Historical Sciences; see Stanley G. Payne, "Jaime Vicens Vives and the Writing of Spanish History," Journal of Modern History, XXXIV (1962), I27.

"Vicens Vives has defined the term "ideologism" as theorizing about the climate of ideas prevailing at a certain point in history on the basis of an analysis of literary texts or official documents. See the prologue to the first edition of Aproximación a la historia de España, pp. I8-20. See also Vicens' review of Américo Castro's book in Indice histórico español, vol. II (1955-56), item 69or.

"For a discussion of the books by Américo Castro, living in exile in the United States, and Claudio Sánchez Albornoz, living in exile in Argentina, see pp. xxi-xxiv. 
histories (by Ramón Menéndez Pidal, ${ }^{6}$ Luis García de Valdeavellano, ${ }^{7}$ and Fernando Soldevila ${ }^{8}$ ) and two dramatic interpretations of the Peninsula's past (by Castro and Sánchez Albornoz). There are also several very distinguished sociological contributions (for example, those of Julio Caro Baroja ${ }^{\theta}$ ), as well as the achievements in the field of economic, socio-economic, and regional history by the Catalan and other schools. In addition, there have been a remarkable number of monographs, books, and magazine articles, which in content are, in general, far superior to those of the preceding two decades.

Reflecting on this material, I am led to believe - and this is my second point - that we find ourselves in a period of transition. In one way this period is characterized by the liquidation of a series of anachronistic positions (in general, those of the scholarly and philological school of Castilian nationalism), and in another way by the birth of a new concept of writing history, responsive to real life and pulsing with human blood, and incompatible with great abstract themes and with those political and ideological drugs that have poisoned Hispanic historiography.

6 Ramón Menéndez Pidal (1869-1968) edited a multivolume history of Spain. Publication began in 1935, but the most important period was I950 to 1958 when six volumes appeared, either for the first time or in a second, revised edition. Menéndez Pidal wrote many of the introductions for these volumes, published by Espasa Calpe in Madrid. During this same period he also published a collection of essays on Spanish literary arid political history, some for the first time: see España y su historia, 2 vols. (Madrid, I957).

7 Luis García de Valdeavellano, Historia de España, vol. I in 2 parts, De los origines a la Baja Edad Media (Madrid: Ist ed., I952; 2d ed., I955; 3d ed., 1964). Valdeavellano was a student of Sánchez Albornoz.

8 Fernando Soldevila, Historia de España, 8 vols. (Barcelona, 1952-59).

${ }^{9}$ Perhaps the major work of Julio Caro Baroja during the decade 1950-I960 is Los Moriscos de Granada: Ensayo de historia social (Madrid, I957). In 1962 he published his most important work to date: Los Judios en la España moderna y contemporánea, 3 vols. (Madrid). He synthesized his findings in his speech upon the occasion of his entry into the Royal Academy of History: "La sociedad cripto-judia en la corte de Felipe IV" (Madrid, I963). For additional bibliographical references, see p. $152 n$. 
The increasing dissemination of new auxiliary methods (demography, economics, sociology, and statistics) warrants the belief that, within a short time, order will be imposed upon whatever has been capricious and unintelligible in Spain's historical jungle, and that clarity and moderation will sweep away the romantic foliage and baroque obscurantism. In other words, we shall become faithful to ourselves, not take refuge in metaphysical speculation in order to avoid a conscious understanding of our past experience.

In the evolution of this historiographical movement, the Barcelona school has during the past seven years been in the vanguard. ${ }^{10} \mathrm{We}$, its members, have toiled without ceasing since January 1953, the same month in which the first edition of this book appeared. During these epic years, through the pages of the Indice histórico español ${ }^{11}$ and of the Estudios de historia moderna, ${ }^{12}$ we have struggled to open new horizons for our science and to liberate it from all fetishes; we have broached subjects not previously considered in our historiography, and we have presented without acerbity aspects formerly embittered by disagreement or else systematically avoided.

As we have advanced, we have found numerous collaborators persons already proceeding in our direction or colleagues who have

10 In the first edition, Vicens cited historians Ramón Gubern, Juan Mercader, and Juan Reglá as other members of the Barcelona school.

11 The Indice histórico español: Bibliografía histórica de España $e$ Hispanoamérica, Io vols. from 1953 to date, a concise summary of reviews of all publications on Spanish and Hispano-American history. It is nominally published by the Center for International Historical Studies, College of Philosophy and Letters, of the University of Barcelona, and thereby gains exemption from the regular state censorship imposed on commercial publications. However, it is in fact printed and distributed by the Teide publishing firm, formerly owned by Vicens and his brother-in-law, Federico Rahola, and since the death of Vicens by Rahola alone.

12 Estudios de historia moderna, begun in I95 I, publishes articles and monographs of original research. Initially appearing under the auspices of the Barcelona Section of the Instituto Jerónimo Zurita, Consejo Superior de Investigaciones Cientificas (the official, government-financed research institution), the journal received an annual state subsidy that was later discontinued. It has appeared only irregularly. 
joined us along the way. ${ }^{13}$ But we have also had to engage in some skirmishes - intellectual ones, needless to say. Victorious or defeated, we bear no grudge toward anyone. We are always ready to welcome historians of good will who come from any camp, group, or school whatsoever. From our circle we regretfully exclude only those persons who leave the arena, carrying with them their political hatreds, and who launch their darts from behind the parapets of comfortable and unearned official redoubts. ${ }^{14}$

I hope I have justified my decision not to reedit this book until now. I might add that, following the inundation of the preceding decade, we now find ourselves in a relatively serene moment. The waters appear to be stilled. Thus I can proceed with my task and push my Approaches towards its second appearance, which I hope will be as fortunate as the first.

But before I begin, I must caution the reader about the methodology that governs the book. Here I have no recourse but to show my credentials as a professional historian, ${ }^{15}$ and the best way I can show them is to repeat a few paragraphs from the prologue I wrote in 1952, modifying them where I deem it necessary.

We all know - I wrote in 1952 - our reaction some thirty years

13 Among the historians who worked with Vicens Vives are Manuel Ballesteros-Gaibrois and Mario Hernández Sánchez-Barba of the University of Madrid, Guillermo Céspedes del Castillo of the University of Seville, and Antonio Domínguez Ortiz of Granada. Specifically, they collaborated in writing the Historia social y. económica de España $y$ América, 4 vols. in 5 parts (Barcelona, 1957-59; reprinted in $196 \mathrm{r}$ under the title Historia de España y America). Vicens directed the entire work, a comprehensive but uneven pioneer study, and wrote the section on nineteenth- and twentieth-century Spain.

14 Vicens is referring to the protection offered by such governmentsubsidized publications as Arbor, the journal of the Consejo Superior de Investigaciones Cientificas. See the first edition of Aproximacion a la historia de España, p. 15.

15 For a complete chronological, annotated bibliography of the publications of Vicens Vives (I910-1960), see Indice histórico español, VI (1960), I-16. For an excellent analysis of Vicens' work, and a description of the difficult political and professional situation in which he worked, see Payne, "Jaime Vicens Vives," Journal of Modern History, pp. I I9-I34. 
ago against the narrative method that prevailed as the norm in university lectures and, above all, as a fundamental guideline for historical research. Since then Spanish historiography has sought a new methodological orientation, at times as an outgrowth of movements originating abroad, at other times attempting its own formulation of the study of the past. These developments have not, however, extinguished a devotion to the old narrative system. It still has many partisans in our country because we find it impossible simply to discard the oldest of historiographical methods. We need only to contemplate the extensive lacunae in Hispanic history to realize that we still must sacrifice a few principles in order to maintain a system which, although it has already failed in its objectives, is indispensable for filling in such lacunae. In order for us to profit directly or indirectly from the work of historical narrators, we ask only that they be thorough and exact in their scholarship and that they be knowledgeable about new methods of research. Quite apart from this, it should be emphasized that it is still useful to publish a good collection of documents on any problem in Spain's internal or external history.

I have purposely used both of the foregoing adjectives. ${ }^{16}$ Because the narrative method was accused of superficiality - it never reached a conclusion of any significance - its place within the national methodology was taken by one called (for what exact reason I do not know) internal history. Those were the years when German procedures invaded our science. Ernst Bernheim was the idol of our professors. ${ }^{17}$ Although the exact results of such a method were not known, everyone surrendered to the almost mythical impact of that name. Ah, internal history! Its dissemination undeniably had great benefits: it put a stop to romantic improvisation, exacted an

16 External history refers to the traditional political or military narratives, internal history to the study of institutions.

17 Ernst Bernheim (1850-1942) published his compendia of methodology, highwater mark of Leopold von Ranke's "scientific" school, in I889 (Lehrbuch der historischen Methode und der Geschichtsphilosophie), revising it substantially in subsequent editions. Not until I937 was there a Spanish translation (Introducción al estudio de la historia, trans. Pascual Galindo Romeo from the 3d ed., I908). 
impartial criticism of sources, and made indispensable an extensive addition of archival material. All of this was needed and welcomed. But because of the simultaneous development of research in the history of law, the new methodological experiment ended up being a cold and sterile history of institutions. ${ }^{18}$ Little by little the human factor, the basis of all historiography, was forgotten. Importance was bestowed upon the framework instead of the contents, upon the conduit of energy instead of the charge which the conduit merely transfers passively. The conduit - the institution - was moved about from one side to the other. These moves filled the texts of conscientious monographs and occasioned formidable scholarly controversies. Today it is sad to contemplate the results that were achieved. One can barely sustain even one of the theses formulated by the great institutional masters at the beginning of the century.

This virus penetrated deep into our medieval field, creating sad havoc when it paired with another, equally dangerous virus, that of pure philology, the myth of the document. ${ }^{19}$ Spanish medieval studies are thus today in a dead-end street where words, not men, are debated. In general, medievalists have forgotten that any word is a carryover from an earlier period and therefore cannot provide

18 In Spain the most prominent institutional historian was Eduardo de Hinojosa (1852-1919), a professor at the University of Madrid; he was active in the Centro de Estudios Históricos, part of the pre-Civil War Junta para la Ampliación de Estudios Históricos (the predecessor organization of the present Consejo Superior). In 1924 Hinojosa's students began publication of the influential Anuario de historia del derecho español. One of these students was Claudio Sánchez Albornoz, who played a key role in the Anuario until he left Spain in 1936.

19 The techniques of philology were introduced into Spain from Germany by Menéndez Pidal, Director of the Real Academia Española (I9261936, I948-I968). Convinced that philology, if used within a broad context, was an important instrument of historiography, he exerted wide influence through his chair at the University of Madrid and as director of the Centro de Estudios Históricos. Américo Castro is one among many who studied with him. For a study of Menéndez Pidal's work in the current historiographical controversy in Spain, see José Antonio Maravall, Menéndez Pidal y la historia del pensamiento (Madrid, I960), pp. 83-160. 
them with a perfect image of the new, vital reality they are trying to define. They have also forgotten that any institution, by the simple act of encasing a vital tension or of achieving a new equilibrium of forces, is stillborn or at least inert. The vital content of an institution comes from the men who use it as the means for fighting to achieve their own ambitions. The passage of time only aggravates this problem, because an institutional body either deforms its social ambience in order to continue representing it, or moves further and further away from expressing the true character of that ambience. I exclude the case in which an institution is converted into myth, for then it loses its "objective reality" and its place at the core of institutional history, and finds a new one in the history of ideas.

Accordingly, although institutional history can show us the approximate channels through which biological energies circulate (which undeniably signifies considerable progress over the accounts of successions of kings and battles I mentioned previously), it does not hold the key to the secret of history. Neither regulations, nor privileges, nor laws, nor constitutions bring us close to human reality. These are formulas that establish limits, but nothing more than limits. The expression of life is to be found in the application of the law, statute, decree, or regulation; in the way in which individuals distort the desire of a state, of a corporation, or of an oligarchy to impose a certain order. An institution should be considered not in and of itself, but in terms of the human fervor that stirs in its innermost recesses. In order to understand such fervor as an historical phenomenon, one must discard the legislative caparison and go directly to the human collectivity that it represents - to human desires, petty pride, and profound resentments, because something of all these is in the Lord's vineyard. For this reason I have unceasingly advocated the need for a radical change in how sources are selected for historical research. Instead of the great collections of laws, historians should consult archives where law clashes with life- notarial protocols, consular and commercial records, police archives, law-court decisions, and so on.

However, simply because today neither the philological method nor that of the history of institutions fully satisfies us does not 
mean we should subordinate them to the more brilliant but far less efficacious method of the so-called history of culture. ${ }^{20}$ Obviously an exploration of the ideological, juridical, emotional, esthetic, religious, and moral aspects of any people will have beneficial results. I do not deny its usefulness. What I do deny is that cultural historians make an objective contribution to our exact knowledge of the Spanish people's past.

I find three important defects in their historical publications. In the first place, every history of a culture has until now required a preliminary intellectual scheme - orthodox or heterodox, materialistic or idealistic, unitary or evolutionary. But life flees from any such circumscription. In the immense majority of cases, life in the process of creating itself (I hope it is obvious I do not mean this in any purely biological or teleological sense) lies far beyond the professional historian's concern. In the second place, until now the history of culture has been nothing more than a study of intellectual minorities, and has therefore examined only a microscopic portion of the mentality at work in any specific period of history. Such a viewpoint is exactly like the old myopic concept that limited political history to the study of some few crowned heads and their followers. Finally, cultural history has not discovered a convincing technique for assessing the relative weights of the spiritual and material contributions of a country or a society. This has given rise to innumerable controversies that have converted cultural history from a spearhead for the vanguard of historical science into a spearhead for political troops disposed to seize power.

Considerations such as these justify the fact that from the beginning of my career as a university professor, I have urged my students to restrict themselves exclusively to the writing of history but to absolute history, to life itself. In order to make my position clear, I wrote in the inaugural issue of Estudios de historia moderna: "Fundamentally we believe that history is life in all its complex

20 By the term "culture," Vicens means specifically the artistic and intellectual history of a nation, rather than the broader sense in which it is used by most modern anthropologists or sociologists. 
diversity. Therefore we do not feel bound by any a priori prejudice against any method, speculative theory, or objective. Materialism we reject as being unilateral, positivism as schematic, ideologism as shallow. We are attempting to capture the living reality of the past and, above all, the interests and passions of the common man."

My experience over the last few years, verified by Spanish and foreign historical publications, leads me to reaffirm this premise. However, if a method is to embrace all of life, it must be carefully defined. To gauge an individual life, one need only know the fundamental principles of the new biographical techniques: the historic moment (the conjecture) penetrating deep within the individual, who reacts to his physical surroundings and to the ambience of his generation according to his psychological potential. But it is much harder to evaluate the past of the common man.

Unless we resort to statistical method as our primary instrument, collective life cannot be deciphered. ${ }^{21}$ In history, statistics is no mere accumulation of data; it is an art of applying percentages and constants, averages and coefficients. It defines clearly how many times men repeat the same offense, without necessarily implying that these men would condemn whatever it is they are doing. Statistics establishes those geographical sites in which the greatest number of major events have taken place. Above all, it expresses numerically the material and spiritual interests of humanity, which are what counts in history. Thus it does not bother me to repeat that statistics is "essential for the determination of values, fortunes, and mentalities," and that "unless this is approached through a minute analysis of prices, salaries, political trends, and cultural tendencies, it is possible to understand nothing."

Nothing: let this point be well understood. Let us imagine we are studying an era, a reign, or a country. It is of scant importance to concentrate on outstanding military or political events. Two successive defeats on the battlefield during this century have not diminished the weight of Germany in the European power system.

21 For the background to this insistence on "quantifiable data," see n. 3, above, on Lucien Febvre's Annales. 
By definition, no institutional body reveals the course of history; glorious names have shielded successive moments of splendor and decadence.

And as for the ideological yardstick, one might commit the very grave error of asserting that five, ten, or twenty individuals (whatever their mental stature) actually represent a reign, a society, or a generation. This is simply not true, not of any twenty in the eighteenth century, nor of any one thousand in our century. An intellectual class represents only itself in its literary production. (When an intellectual participates in politics or takes a streetcar, the case is different, for this activity must be evaluated as a function of his new role.) Consequently, one must determine what interests an intellectual serves through the medium of his specific profession. Such interests are the basic human ones: interests directly related to his employment and to the office he holds; the interests of the groups he belongs to; the material and moral pressures exerted by those upon whom he is dependent; psychological complexes such as routine, fear, ambition, and envy; concretely spiritual interests; and so on. Therefore, when trying to establish successive generations in the history of ideas, one must not fall into the error of generalizing by saying "So-and-so thought in that way; everyone must have thought that way." The history of ideas is far more capillary; in order to take full account of this, one must broaden research and consult neutral archives, that is, those archives that candidly reflect our ancestors' "intellectual pluralism."

This leads us back once more to the statistical method. The historian who does not use it is deprived of his best working tool, in the same way that government officials cannot function without the data supplied by statistical services. Even when we know personally the living reality of a country, we must still submerge ourselves in the sea of facts provided by annual publications, to try to take the exact pulse of that country by means of data on population, production, wealth, culture, sanitation, labor, and so on - data, with which the intellectual's pen never deals. If this be the case, how much greater would the benefit be if, when examining the societies of the 
past, we reformulated such data? Historical science, particularly in Spain, would take a great step forward if the statistics of the past were done over. Fortunately we are already working in this field, but the harvest is great and those who can work on it are few.

In redoing the configuration of his own history by using the new methods cited above, the Spanish historian should make some contribution to the methodology of the future. Even the most progressive circles abroad continue to debate this matter. The problem to be resolved is that of integrating demographic, social, economic, and psychological techniques - based on statistics - into a totality that can be termed a "method of the sciences of man."

There are two aspects to the resolution of this problem: the epistemological (about which it is better to allow philosophers the last word), and the distinctively scholarly. About the latter, it is feasible for me to offer an opinion, by resorting not to the metaphysics of the human being or of the event (as is common among present-day Castilian scholastics) but to the simple and modest task of studying material taken directly from the archives. The difficulties involved in this task of original research have led to certain experiments which, although they are at the moment of limited use, will with time be integrated into a more general formula. In recent years these have constituted our most valuable system of collaborating with foreign colleagues, and the one for which we have been most grateful to them.

Before concluding this already extended prologue, I must express my concern about a reaction the reader may have. Perhaps he may find it strange that my Approaches does not actively engage in the controversy that today divides Hispanic historians and Hispanists in general, some of whom have declared their support for the thesis of Américo Castro ${ }^{22}$ and others for the thesis of Claudio Sánchez

22 Américo Castro (b. I 885), La realidad histórica de España (Mexico City, 1954). Professor Edmund King of Princeton University has translated it into English under the title, The Structure of Spanish History (Princeton, 1954). Castro's book is a greatly modified version of his earlier work, España en su historia: Cristianos, moros, y judios (Buenos Aires, 1948). 
Albornoz. ${ }^{23}$ This book is not a critical study, nor is it an essay. It attempts to provide orientation and guidelines for research, and to establish the point at which we have arrived and the point at which we could arrive in the near future. Therefore it has not diverged from its original format of absolute adherence to the practice results of research. If anything in these pages has changed since the first edition, it is not because I have changed my criterion, but because of the progress achieved (after ten years of productive work in the archives) in subject matter and in the formulation of the problems of Spanish history.

Nevertheless, I do not want to abandon this comfortable refuge of a prologue without entering the lists. In my judgment, the work of both masters constitutes a singular and intelligent contribution which we must gratefully acknowledge. To write a history of Spain today without taking into account La realidad histórica de España or España: Un enigma histórico would be inconceivable.

At this point I do not think it important to discuss the methods of these two authors, which are very different (especially that of Américo Castro) from the statistical method that I have just commended. I would even go so far as to affirm that both of their methods have been largely superseded, although in doing so I am well aware that I will bring down upon myself fulminous rays from each Olympus. What interests me in both these works is the broad presentation of Spain's problems in antiquity and the Middle Ages, and in the modern era up to the seventeenth century. Many facts and events have been discussed (at times with excessive scholarly tolerance on the part of Castro, and with excessive commitment to Castile on the part of Sánchez Albornoz), so much so that Don Américo and Don Claudio - who set themselves a task of sifting have left a very fine flour of good quality. A hurricane wind has carried off the chaff; let it be noted that there was a lot of it, and that it had had a great historical impact. This invaluable sifting will

23 Two years after Castro's book was published, Claudio Sánchez Albornoz (b. 1893) published España: Un enigma histórico, 2 vols. (Buenos Aires, 1956; 2d, rev. ed., 1962); it tends to be a point-by-point refutation of Castro's arguments. 
greatly benefit all consciences, particularly when its results are publicized and when they actually affect the conscience of Castile.

As a matter of fact, Castile has been confronted with a grave crisis of conscience since 1898 . She would like to attribute the origins of the crisis which is disturbing her to the negative attitude of other Hispanic peoples - for example, to the attitude of Catalans. This is a most understandable reaction, and one that is even salutary for Castile's collective psychology, given the intrinsic conflict between Castile and Catalonia - a conflict that since the eighteenth century has constituted both a vital stimulus for, and the cohesive force of, the Spanish state.

Castile supposedly resolved the crisis of 1898 by an act of nationalistic willpower. Strangely enough, this nationalism was not based on a study of history. The single exception was the group in the University of Madrid that gathered around Ramón Menéndez Pidal and Manuel Gómez Moreno. Neither Miguel de Unamuno nor José Ortega y Gasset turned to history; both approached the Castilian through an experience that was very personal and, simultaneously, eternal. ${ }^{24}$ From this approach emerged an unreal Castile that has been perpetuated up until now by all the men of that earlier generation and, even more, by their followers.

But in 1955 this same Castile - in the person of two of her most characteristic historians - considered the possibility that now it may be necessary to plunge into a study of her history in order to resolve what she believes to be an excruciating problem of conscience. One part of the problem is Spain's inability to follow the course of Western civilization in its economic, political, and cultural aspects capitalism, liberalism, and rationalism. Another is that Castile has failed in her appointed role of making Spain a harmonious, satisfied, and compliant community. Both these themes are interwoven in the pages of the books by Castro and Sánchez Albornoz; although both authors might think it impossible, they are reconciled in this

24 For the effect of these intellectuals on Spanish historiography, see Richard Herr, "The Twentieth-Century Spaniard Views the Spanish Enlightenment," Hispania (1962), pp. 183-193. 
one gigantic accord. It could not be otherwise, even though Castro tries to explain this failure by the ending of medieval Castile's intellectual pluralism, whereas Sánchez Albornoz tries to explain it in terms of what he calls (it cannot be reduced to a clearer synthesis) "the short circuit of modernity": Castile's paralysis in the sixteenth century, caused by her threefold effort to be a European, colonial, and dynastic power.

The dimensions of the controversy aroused by these historians (which has involved all of us who cultivate this science on the Peninsula) lead one to suspect that it will be productive. It will be particularly so if in its resolution, stereotypes and platitudes are abandoned, and the basic factors of Peninsular history are set forth: men, misery, and famine; epidemics and death; land ownership; the relations between a lord and his vassal, between a government official and the citizen subject to his jurisdiction, between an employer and a worker, between a monarch and his subject, between a priest and a believer, between one municipal government and another, between town and town, between national capital and province, between individual production and national income, between a soul and God. These factors do not differ greatly from those that underlie the experience of neighboring Mediterranean nations; for this reason it is very doubtful that Spain is "a historic enigma" as Sánchez Albornoz believes, or that it is "un vivir desviviéndose" as his opponent declares. ${ }^{25}$ This is too much anguish, Unamuno style, for a Mediterranean community with very concrete and compact "epoch-making" problems - the problems of procuring a modest but dignified livelihood for its thirty million inhabitants.

I have strayed so far off the path that I will conclude with a very few words to draw attention to the innovations in the text - two

25 Explaining his term "vivir desviviéndose," Castro writes that many eminent Spaniards "have tried to explain the existence of Spain as a chronic ailment. ... It has not befallen any other great civilization to live for century after century feeling all the while that the very ground under its feet was missing and creating at the same time such first-class values." Structure of Spanish History, pp. 29-30. 
chapters dealing with prehistoric life, and one dealing with the culminating moment of medieval life. At the end of the book I have added a commentary on each chapter, in which I set forth my opinions on very controversial points or discuss certain very categorical affirmations; these are neither critical nor bibliographical studies, but rather a kind of log of my intellectual itinerary.

February 1960

Jaime Vicens Vives 
